Short Note

\title{
Isolation and Characterization of Microsatellite Markers in Brown Planthopper (Nilaparvata lugens Stål)
}

\section{Shengli Jing, Xi Zhou, Hangjin Yu, Bingfang Liu, Chunxiao Zhang, Shuzhen Wang, Xinxin Peng, Lili Zhu, Yi Ding and Guangcun He *}

State Key Laboratory of Hybrid Rice, College of Life Science, Wuhan University, Wuhan 430072, Hubei Province, China; E-Mails: jsl80@163.com (S.J.); cathychou@whu.edu.cn (X.Z.); yhj@whu.edu.cn (H.Y.); bingfangliu@163.com (B.L.); emilyat10@126.com (C.Z.); wangshuzhen04@163.com (S.W.); fred_pxx@126.com (X.P.); zhulili58@sina.com (L.Z.); yiding@whu.edu.cn (Y.D.)

* Author to whom correspondence should be addressed; E-Mail: gche@whu.edu.cn; Tel.: +86-27-6875-2384; Fax: +86-27-6875-2327.

Received: 15 May 2012; in revised form: 22 June 2012 / Accepted: 16 July 2012 / Published: 27 July 2012

\begin{abstract}
Brown planthopper (Nilaparvata lugens Stål) (Homoptera: Delphacidae) is an economically important pest on rice. In this study, 30 polymorphic microsatellite markers were developed from $N$. lugens genomic libraries using the method of Fast Isolation by AFLP of Sequence Containing Repeats (FIASCO). Polymorphism of each locus was detected in 48 individuals from two natural populations. These microsatellite loci revealed 2 to 18 alleles, and the expected and observed heterozygosities ranged from 0.042 to 0.937 and from 0.042 to 0.958 , respectively. These markers will be useful for the future study of this agricultural pest in population genetics and molecular genetics.
\end{abstract}

Keywords: Nilaparvata lugens; microsatellites; polymorphism; genetic diversity

\section{Introduction}

Brown planthopper (Nilaparvata lugens Stål) (Homoptera: Delphacidae) is a specialist insect pest of rice which does great damage to the rice plants not only directly by consuming the plants sap but also indirectly by transmitting rice viruses such as ragged stunt virus or grassy stunt virus. Many Asia rice-producing countries are frequently reported to have suffered significant damage and heavy yield 
losses due to brown planthopper [1]. Moreover, brown planthoppers are found to have adapted to the variety of host rice and formed new populations, which can break host plant's resistance [2]. Therefore, it is important to study the population ecology and evolution of this pest. SSR, with advantages of multi-allelic behavior, co-dominance, abundance and high information content, have been developed for many species [3]. So far, the EST-SSR markers of brown planthopper have been developed for studying genetic diversity of the natural populations [4,5] and the experimental populations [6]. In general, genomic SSR markers are more polymorphic than EST-SSRs. In this study, we have developed and characterized another 30 genomic SSR markers for $N$. lugens.

\section{Results and Discussion}

A total of 136 primer pairs were designed from microsatellite sequences isolated from partial genome libraries by a standard Fast Isolation by AFLP of Sequence Containing Repeats (FIASCO) protocol. Out of them, sixty-two successfully yielded clear bands while the others showed multi-banding patterns or no amplification. Then, these primers were further tested in two natural populations of $N$. lugens collected from Wuhan, Hubei Province (Wuhan population) and Wuyishan, Fujian Province (Wuyishan population), respectively. Among them, 30 markers showed polymorphism between these two populations (Table 1); and the amplification products are within the expected size range.

Table 1. Characteristics of 30 new microsatellite markers developed in Nilaparvata lugens.

\begin{tabular}{|c|c|c|c|}
\hline Locus & Repeat motif & Primer sequence $\left(5^{\prime}-3^{\prime}\right)$ & GenBank accession No. \\
\hline \multirow{2}{*}{ BM1362 } & \multirow{2}{*}{$(\mathrm{AAGT}) 3$} & F: TGGGCAAGACCATCTTGATA & \multirow{2}{*}{ JQ967334 } \\
\hline & & R: CGAATTCAAATGGGAAGTCTGT & \\
\hline \multirow{2}{*}{ BM1368 } & \multirow{2}{*}{ (AG)10 } & F: AGGGATTCAGATTCAGGGAGA & \multirow{2}{*}{ JQ967337 } \\
\hline & & R: CGGTGGAGATGAAAGTGGAC & \\
\hline \multirow{2}{*}{ BM1369 } & \multirow{2}{*}{$(\mathrm{AG}) 9$} & F: TCGTGCAGAAGCGAAAGAAT & \multirow{2}{*}{ JQ967338 } \\
\hline & & R: TTTTTCAACTCGTCAGCATGT & \\
\hline \multirow{2}{*}{ BM1372 } & \multirow{2}{*}{$(\mathrm{AT}) 6$} & F: GTGCAACCACGAGCATTTC & \multirow{2}{*}{ JQ967341 } \\
\hline & & R: AAGACСССТTCСТCAGCATC & \\
\hline \multirow{2}{*}{ BM1373 } & \multirow{2}{*}{$(\mathrm{CT}) 7$} & F: CСАСАТТССАССТСТТТТСА & \multirow{2}{*}{ JQ967340 } \\
\hline & & R: AGTGCGCAGAAACTTGATGA & \\
\hline \multirow{2}{*}{ BM1375 } & \multirow{2}{*}{$(\mathrm{GA}) 8$} & F: TCCATGAGAAAGAGGGCTTG & \multirow{2}{*}{ JQ967346 } \\
\hline & & R: GCTGAGGCCTTACCTATCAAA & \\
\hline \multirow{2}{*}{ BM1377 } & \multirow{2}{*}{$(\mathrm{CTT}) 4$} & F: TACACTAACGCACGCACACA & \multirow{2}{*}{ JQ967347 } \\
\hline & & R: TCAACGGTAAAGGGAGAAGG & \\
\hline \multirow{2}{*}{ BM1378 } & \multirow{2}{*}{$(\mathrm{TG}) 7$} & F: CATCATTGCAACGTTCATCC & \multirow{2}{*}{ JQ967348 } \\
\hline & & R: GCCСТCCAAATTAGGTCTCC & \\
\hline \multirow{2}{*}{ BM1392 } & \multirow{2}{*}{$(\mathrm{AAG}) 4$} & F: GAAGCTGAAAAAGAAAGATGAAGAA & \multirow{2}{*}{ JQ967349 } \\
\hline & & R: TTTGCCTCAATTTTGCTCCT & \\
\hline \multirow{2}{*}{ BM1393 } & \multirow{2}{*}{$(\mathrm{CCT}) 5$} & F: АССТСТСССССТСАТСАТТС & \multirow{2}{*}{ JQ967350 } \\
\hline & & R: TGGTTTGGTGTTCGATGCTA & \\
\hline \multirow{2}{*}{ BM1415 } & \multirow{2}{*}{$(\mathrm{TC}) 6$} & F: CGGTCCAAAAATGGAAAATG & \multirow{2}{*}{ JQ967360 } \\
\hline & & R: GGGTGTGTGCCATGATTTAG & \\
\hline
\end{tabular}


Table 1. Cont.

\begin{tabular}{|c|c|c|c|}
\hline Locus & Repeat motif & Primer sequence $\left(5^{\prime}-3^{\prime}\right)$ & GenBank accession No. \\
\hline \multirow{2}{*}{ BM1417 } & \multirow{2}{*}{ (TGAA)3 } & F: TGAGTTGGAAGGTGTCATGG & \multirow{2}{*}{ JQ967353 } \\
\hline & & R: TCCTCAATGGACСТСТСТССТ & \\
\hline \multirow{2}{*}{ BM1418 } & \multirow{2}{*}{$(\mathrm{ATG}) 5$} & F: GAAAGAAAATGGAGCCGTCA & \multirow{2}{*}{ JQ967354 } \\
\hline & & R: ACCCATGCCTCTTTCСТСTT & \\
\hline \multirow{2}{*}{ BM1420 } & \multirow{2}{*}{$(\mathrm{GAAG}) 3$} & F: GAAACTTGGTGAGGGGATCA & \multirow{2}{*}{ JQ967342 } \\
\hline & & R: TTCTTTGTTCACAATTTTCTCAGC & \\
\hline \multirow{2}{*}{ BM1422 } & \multirow{2}{*}{$(\mathrm{GA}) 6$} & F: TAAGGCGAGAAAGTGCGATT & \multirow{2}{*}{ JQ967343 } \\
\hline & & R: СТТТСТСССАСТТССССАТС & \\
\hline \multirow{2}{*}{ BM1423 } & \multirow{2}{*}{$(\mathrm{GAT}) 6$} & F: GGAGGAGGTCGAGGAAGAAT & \multirow{2}{*}{ JQ967344 } \\
\hline & & R: TCСТССАТТССТТСТTСТTGTT & \\
\hline \multirow{2}{*}{ BM1432 } & \multirow{2}{*}{$(\mathrm{GA}) 7$} & F: GTGACAAAGAGCGAGGGAGT & \multirow{2}{*}{ JQ967335 } \\
\hline & & R: CGCССТАACTTAСССТGСТА & \\
\hline \multirow{2}{*}{ BM1433 } & \multirow{2}{*}{$(\mathrm{AG}) 8$} & F: TGCAGAGAGATGAGGCAAAA & \multirow{2}{*}{ JQ967336 } \\
\hline & & R: TTTCGCACAACGTACTGCTC & \\
\hline \multirow{2}{*}{ BM1437 } & \multirow{2}{*}{$($ TCAA)3 } & F: CAAACAATAGCGAGCATTACAGA & \multirow{2}{*}{ JQ967339 } \\
\hline & & R: CCAGCGTTATTGTCCTGTCA & \\
\hline \multirow{2}{*}{ BM1443 } & \multirow{2}{*}{$(\mathrm{GATT}) 4$} & F: TCСТТСССАТСААТАСАAGACC & \multirow{2}{*}{ JQ967346 } \\
\hline & & R: TCAAGCCCTCTTTCTCATGG & \\
\hline \multirow{2}{*}{ BM1446 } & (ТC) 11 & F: TTTGTCGGAGCGATCTCTTT & IO967345 \\
\hline & (IC) 11 & R: CGCTGTCCATTCAACAAATG & JQ96/345 \\
\hline BM1456 & (TAA) 5 & F: TGGAAGTGAAACTGCAAGAAAA & IO967357 \\
\hline DVIIIJU & נינ) & R: TTGCGACCTGAAAACTCTGA & (T) \\
\hline BM1462 & $(\mathrm{AAG}) 12$ & F: GTCCGGGCTTAGCCTTTTAT & IO967351 \\
\hline & $(A A G) 12$ & R: GCATCTAACGGGTGATTCTCA & पQ $250 / 501$ \\
\hline PM1161 & $(\Delta C) 7$ & F: CATTCACAGCTGAGGTATGAGG & IOQ67250 \\
\hline DIVII 404 & $(A G) /$ & R: CACAGCTTGACTCAСССТСТC & JQ290/359 \\
\hline BM1471 & $(\mathrm{AAG}) 4$ & F: CGAAGCGGAAATAGATGGTT & IO967355 \\
\hline DIVI14/1 & $(A A G) 4$ & R: CACATTTTCCAGGCTTCACC & JQ $90 / 355$ \\
\hline BM1472 & $(\mathrm{GAA}) 7$ & F: GGGAAGGGGAGAAGTCAAAG & IO967350 \\
\hline Div114/2 & $(G A A) /$ & R: САТТССАССТССТТСТТССА & JQ96/358 \\
\hline BM1476 & $(\mathrm{GAAGGA}) 4$ & F: CGACGGAAAATCAGTCATCA & IO967356 \\
\hline$D 10114 / 0$ & (GAAGGA) 4 & R: CCTGCTTCACATCСТССТTC & JQ96/356 \\
\hline BM1483 & (AАТ)4 & F: GCGTTTGAGCGTGGTTTCTA & JO967352 \\
\hline & & R: ATGGAGTGGGTCCACCAATA & \\
\hline BM1486 & $(A A G) 5$ & F: AAAAATGGATGGGAAAGGAGA & IO967354 \\
\hline & & R: ССТТССАТССТТТТАТТСТТСТСА & Q200/304 \\
\hline BM1490 & (CT) 11 & F: GTCAAATCCCTGGCACATTT & IO967344 \\
\hline D.1911450 & (4) 11 & R: TGAAGTGAATGAAACCCACATC & Q \\
\hline
\end{tabular}

It was found that the degree of polymorphism between two populations was not significantly different. The average number of detected alleles per locus and the mean observed heterozygosity for two populations were also similar. In the Wuhan population of $N$. lugens, the numbers of detected alleles per locus in 24 individuals ranged from 2 to 16, with an average of 9.2 alleles for the 30 markers. The expected and observed heterozygosities ranged from 0.042 to 0.910 (mean 0.717) and from 
0.042 to 0.958 (mean 0.515), respectively (Table 2). The degree of polymorphism of BM1373 was the highest in the Wuhan population. Twenty-one loci (BM1362, BM1368, BM1369, BM1375, BM1377, BM1378, BM1392, BM1393, BM1417, BM1422, BM1423, BM1432, BM1433, BM1443, BM1446, BM1456, BM1462, BM1464, BM1472, BM1486 and BM1490) deviated significantly from HWE $(p<0.05)$ due to heterozygote deficiency, and null alleles were found in these loci except two (BM1362 and BM1486).

Table 2. Diversity estimation in two populations of Nilaparvata lugens.

\begin{tabular}{|c|c|c|c|c|c|c|c|c|c|c|}
\hline \multirow{2}{*}{ Locus } & \multicolumn{5}{|c|}{ Population WH $(n=24)$} & \multicolumn{5}{|c|}{ Population WYS $(n=24)$} \\
\hline & $N_{\mathrm{a}}$ & $H_{0}$ & $\boldsymbol{H}_{\mathrm{e}}$ & $D$ & $S$ & $N_{\mathrm{a}}$ & $H_{0}$ & $\boldsymbol{H}_{\mathrm{e}}$ & $D$ & $S$ \\
\hline BM1362 & 4 & 0.292 & 0.393 & $*$ & $232-246$ & 5 & 0.292 & 0.425 & NS & 232-252 \\
\hline BM1368 & 9 & 0.391 & 0.844 & $*$ & $130-162$ & 10 & 0.292 & 0.544 & $*$ & 138-168 \\
\hline BM1369 & 11 & 0.667 & 0.877 & $*$ & 182-208 & 9 & 0.409 & 0.819 & * & 186-308 \\
\hline BM1372 & 2 & 0.042 & 0.042 & NS & $200-204$ & 2 & 0.042 & 0.191 & $*$ & 200-204 \\
\hline BM1373 & 15 & 0.958 & 0.902 & NS & $110-152$ & 16 & 0.875 & 0.928 & NS & 116-172 \\
\hline BM1375 & 11 & 0.583 & 0.853 & $*$ & 180-206 & 12 & 0.625 & 0.886 & $*$ & 180-238 \\
\hline BM1377 & 9 & 0.458 & 0.732 & $*$ & $194-224$ & 6 & 0.542 & 0.722 & NS & $187-232$ \\
\hline BM1378 & 12 & 0.375 & 0.883 & $*$ & $192-240$ & 18 & 0.409 & 0.937 & $*$ & $168-240$ \\
\hline BM1392 & 13 & 0.542 & 0.766 & * & $148-280$ & 15 & 0.545 & 0.814 & * & $130-250$ \\
\hline BM1393 & 5 & 0.250 & 0.527 & $*$ & $186-246$ & 10 & 0.375 & 0.707 & $*$ & $186-246$ \\
\hline BM1415 & 7 & 0.708 & 0.701 & NS & $192-212$ & 7 & 0.542 & 0.448 & NS & $180-216$ \\
\hline BM1417 & 3 & 0.273 & 0.588 & $*$ & 180-200 & 4 & 0.458 & 0.621 & $*$ & 180-204 \\
\hline BM1418 & 9 & 0.583 & 0.689 & NS & 164-194 & 8 & 0.542 & 0.743 & $*$ & 164-194 \\
\hline BM1420 & 6 & 0.292 & 0.270 & NS & $212-260$ & 4 & 0.478 & & NS & 200-260 \\
\hline BM1422 & 10 & 0.500 & 0.853 & $*$ & $182-206$ & 13 & 0.565 & 0.921 & $*$ & 178-204 \\
\hline BM1423 & 13 & 0.652 & 0.909 & $*$ & $217-320$ & 13 & 0.636 & 0.874 & $*$ & 220-379 \\
\hline BM1432 & 15 & 0.739 & 0.910 & $*$ & 130-218 & 12 & 0.261 & 0.875 & $*$ & 140-218 \\
\hline BM1433 & 12 & 0.565 & 0.898 & $*$ & $184-250$ & 13 & 0.591 & 0.906 & $*$ & 186-244 \\
\hline BM1437 & 7 & 0.500 & 0.505 & NS & $182-230$ & 6 & 0.565 & 0.593 & NS & $174-230$ \\
\hline BM1443 & 11 & 0.348 & 0.750 & $*$ & $168-240$ & 7 & 0.542 & 0.588 & NS & 160-202 \\
\hline BM1446 & 16 & 0.652 & 0.907 & $*$ & $164-254$ & 13 & 0.609 & 0.891 & $*$ & 170-254 \\
\hline BM1456 & 10 & 0.458 & 0.828 & $*$ & $140-220$ & 5 & 0.500 & 0.582 & $*$ & $180-260$ \\
\hline BM1462 & 12 & 0.739 & 0.901 & $*$ & 179-260 & 11 & 0.792 & 0.855 & NS & 179-216 \\
\hline BM1464 & 5 & 0.500 & 0.739 & $*$ & $182-280$ & 4 & 0.556 & 0.743 & NS & $182-280$ \\
\hline BM1471 & 4 & 0.682 & 0.601 & NS & $201-252$ & 4 & 0.300 & 0.750 & $*$ & 198-252 \\
\hline BM1472 & 12 & 0.333 & 0.895 & $*$ & $161-238$ & 15 & 0.565 & 0.919 & $*$ & $138-260$ \\
\hline BM1476 & 6 & 0.500 & 0.429 & NS & $180-222$ & 8 & 0.818 & 0.648 & NS & $180-240$ \\
\hline BM1483 & 8 & 0.708 & 0.679 & NS & $204-243$ & 10 & 0.810 & 0.724 & NS & $207-261$ \\
\hline BM1486 & 6 & 0.583 & 0.736 & $*$ & 190-217 & 7 & 0.667 & 0.707 & NS & 190-262 \\
\hline BM1490 & 14 & 0.583 & 0.902 & $*$ & $184-238$ & 12 & 0.708 & 0.887 & $*$ & $176-210$ \\
\hline Mean & 9.2 & 0.515 & 0.717 & - & - & 9.3 & 0.530 & 0.724 & - & - \\
\hline
\end{tabular}

$N$ : population sample size; $H_{\mathrm{O}}$ : observed heterozygosity; $H_{\mathrm{e}}$ : expected heterozygosity; $N_{\mathrm{a}}$ : number of alleles; $D$ : deviation from Hardy-Weinberg equilibrium; $S$ : Size range (bp); NS: not significant; *: significant deviations from Hardy-Weinberg expectations $(p<0.05)$; Population WH: Wuhan population; Population WYS: Wuyishan population. 
In the Wuyishan population, the numbers of detected alleles per locus in 24 individuals ranged from 2 to 18, with an average of 9.3 alleles per locus. The expected and observed heterozygosities ranged from 0.191 to 0.937 (mean 0.717 ) and from 0.042 to 0.875 (mean 0.530), respectively. The degree of polymorphism of BM1373 was also the highest in the Wuyishan population. Eighteen loci (BM1368, BM1369, BM1372, BM1375, BM1378, BM1392, BM1393, BM1417, BM1418, BM1422, BM1422, BM1432, BM1433, BM1446, BM1456, BM1471, BM1472 and BM1490) deviated significantly from HWE $(p<0.05)$ due to heterozygote deficiency, and null alleles were found in these loci except three (BM1417, BM1418 and BM1456).

The statistical significance of the linkage disequilibrium among 30 microsatellite loci was tested by Fisher's exact probability test. Linkage disequilibrium $p$-values were obtained for 435 pairs of marker combinations. Out of these, 79 (18.2\%) pairs in the Wuhan population and 91 (20.9\%) pairs in the Wuyishan population, showed significant LD at $p<0.05$, respectively.

Genomic SSR markers appear to be more polymorphic in this study. Both the number of alleles and the observed heterozygosity of genomic SSR dataset are higher than those of two EST-SSR datasets [5,6]. In Liu and Hou's study, the number of alleles ranged from two to five, and the observed heterozygosity ranged from 0.111 to 0.411 . In Jing's study, the number of alleles ranged from two to seven, and the average observed heterozygosity for four populations ranged from 0.43 to 0.52 . In this study, these microsatellite loci revealed 2 to 18 alleles, and the observed heterozygosities ranged from 0.042 to 0.958 . Therefore, these microsatellite loci are better than EST-SSRs for genetic diversity study and the construction of linkage map of $N$. lugens.

The observed heterozygosity was lower than the expected heterozygosity in all loci except seven (BM1415, BM1420, BM1476 and BM1483 in both populations; BM1372, BM1373 and BM147 in the Wuyishan population). Several factors may lead to the observed heterozygosity being less than expected heterozygosity in a population, such as the presence of null alleles and sex-linkage that are two aspects of great importance for explaining the disequilibrium of HW. In this study, the null alleles were present in many loci, while the evidence of sex was not found because only female adults were used. Therefore, further investigation for these two factors is needed in future studies, especially for the sex-like loci.

\section{Experimental Section}

The genomic DNA was extracted from a female individual of $N$. lugens with a CTAB protocol [7]. The $(\mathrm{AC})_{13}$ and (AAG) $)_{8}$-enriched partial genomic libraries were constructed, employing a AFLP (amplified fragment length polymorphism) of sequences containing repeats (FIASCO) protocol [8]. Fragments containing microsatellite repeats were cloned into pUC18-T vector (TaKaRa) and transformed into TOP10 cells. Finally, 219 positive clones with suitable insert length were identified and sequenced using an ABI 3730 DNA sequencer.

189 sequences were obtained and screened for the SSR motifs using the SSRIT discover program [9]. As a result, 87 sequences contained at least one microsatellite locus, and 136 primer pairs were designed by using BatchPrimer3 [10]. For all PCR amplifications, we used a PTC-100 thermal cycler (MJ Research) and performed in $10 \mu \mathrm{L}$ volumes containing 10 ng of template DNA, $0.3 \mu \mathrm{M}$ of each of the two primers, $0.2 \mathrm{mM}$ deoxynucleotide triphosphates (dNTPs), $2.5 \mathrm{mM} \mathrm{MgCl}, 1 \times \mathrm{PCR}$ 
buffer, and 1 unit of Taq DNA polymerase (Fermentas). The PCR cycling program, in each case, was $94{ }^{\circ} \mathrm{C}$ for $5 \mathrm{~min}$, followed by 35 cycles of $94^{\circ} \mathrm{C}$ for $15 \mathrm{~s}, 55^{\circ} \mathrm{C}$ for $15 \mathrm{~s}$, and $72{ }^{\circ} \mathrm{C}$ for $30 \mathrm{~s}$, with a final extension step of $72{ }^{\circ} \mathrm{C}$ for $10 \mathrm{~min}$. PCR amplification products were size-fractionated by electrophoresis on $6 \%$ denaturing polyacrylamide sequencing gels that were run at a constant power of $60 \mathrm{~W}$, and then detected by silver staining [11]. Allele sizes were scored by comparison with pBR322 DNA/MspI DNA size markers (Tiangen Biotech).

The level of polymorphism was determined for 48 female adults from two populations of $N$. lugens collected from rice fields in Wuhan, Hubei Province and in Wuyishan, Fujian Province, China. For each locus, the number of alleles $\left(N_{\mathrm{a}}\right)$, observed heterozygosity $\left(H_{0}\right)$, expected heterozygosity $\left(H_{\mathrm{e}}\right)$, tests for linkage disequilibrium (LD) and deviations from Hardy-Weinberg equilibrium (HWE) were calculated by the software Arlequin 3.1 [12]. The occurrence of a null allele was estimated by the software MICRO-CHECKER [13].

\section{Conclusions}

In summary, 30 microsatellite markers have been developed from Nilaparvata lugens, and reveal a high degree of polymorphism among individuals in two natural populations. These markers are useful for population genetic diversity and molecular genetics study of this agricultural pest.

\section{Acknowledgment}

This work was supported by the Fundamental Research Funds for the Central Universities of China (grant number 114050).

\section{References}

1. Bentur, J.S.; Viraktamath, B.C. Rice planthoppers strike back. Curr. Sci. 2008, 95, 441-443.

2. Pathak, M.D. Utilization of Insect-Plant Interactions in Pest Control. In Insects, Science and Society; Pimentel, D., Ed.; Academic Press: London, UK, 1975; pp. 121-148.

3. Powell, W.; Machray, G.C.; Provan, J. Polymorphism revealed by simple sequence repeats. Trends Plant Sci. 1996, 1, 215-222.

4. Sun, J.T.; Zhang, Y.K.; Ge, C.; Hong, X.Y. Mining and characterization of sequence tagged microsatellites from the brown planthopper Nilaparvata lugens. J. Insect Sci. 2011, 11, 1-11.

5. Liu, Y.D.; Hou, M.L. Development of EST-SSRs in the brown planthopper Nilaparvata Lugens. In permanent genetic resources added to molecular ecology resources database 1 January 2009-30 April 2009. Mol. Ecol. Resour. 2009, 9, 1375-1429.

6. Jing, S.L.; Liu, B.F.; Peng, L.; Peng, X.X.; Zhu, L.L.; Qiang, F.; He, G.C. Development and use of EST-SSR markers for assessing genetic diversity in the brown planthopper (Nilaparvata lugens Stål). Bull. Entomol. Res. 2012, 102, 113-122.

7. Tang, M.; Lv, L.; Jing, S.L.; Zhu, L.L.; He, G.C. Bacterial symbionts of the brown planthopper, Nilaparvata lugens (Homoptera: Delphacidae). Appl. Environ. Microbiol. 2010, 76, 1740-1745.

8. Zane, L.; Bargelloni, L.; Patarnello, T. Strategies for microsatellite isolation: A review. Mol. Ecol. 2002, 11, 1-16. 
9. Gramene Ssrtool. Available online: http://www.gramene.org/db/markers/ssrtool (accessed on 28 July 2005).

10. You, F.M.; Huo, N.; Gu, Y.Q.; Luo, M.C.; Ma, Y.; Hane, D.; Lazo, G.R.; Dvorak, J.; Anderson, O.D. BatchPrimer3: A high throughput web application for PCR and sequencing primer design. BMC Bioinforma. 2008, 9, doi:10.1186/1471-2105-9-253.

11. Han, Y.C.; Teng, C.Z.; Hu, Z.L.; Song, Y.C. An optimal method of DNA silver staining in polyacrylamide gels. Electrophoresis 2008, 29, 1355-1358.

12. Excoffier, L.; Laval, G.; Schneider, S. Arlequin ver. 3.0: An integrated software package for population genetics data analysis. Evol. Bioinforma. Online 2005, 1, 47-50.

13. Van Oosterhout, C.; Hutchinson, W.F.; Wills, D.P.M.; Shipley, P. MICRO-CHECKER: Software for identifying and correcting genotyping errors in microsatellite data. Mol. Ecol. Notes 2004, 4, 535-538.

(C) 2012 by the authors; licensee MDPI, Basel, Switzerland. This article is an open access article distributed under the terms and conditions of the Creative Commons Attribution license (http://creativecommons.org/licenses/by/3.0/). 